\title{
Deliberate hypotension in orthopedic surgery reduces blood loss and transfusion requirements: a meta-analysis of randomized controlled trials
}

\author{
[L’hypotension délibérée en chirurgie orthopédique réduit les pertes sanguines et \\ l'incidence transfusionnelle: une méta-analyse d'études randomisées contrôlées]
}

James Edward Paul MD MSC FRCPC, Elizabeth Ling MD MSC FRCPC, Carlos Lalonde MD, Lehana Thabane PhD

Purpose: To determine if deliberate hypotension decreases blood loss and transfusion requirements in patients undergoing orthopedic surgery, a systematic review of all randomized trials addressing this issue was undertaken.

Methods: Electronic databases, citations lists and review articles were searched for potential articles. Relevant articles met the following inclusion criteria: English language, humans undergoing orthopedic surgery, deliberate hypotension used by any method, intraoperative blood loss measured as an outcome, and the trial methodology being randomized and controlled. Four outcomes were analyzed, including estimated blood loss, blood transfused, surgery duration, and quality of the surgical field. For all analyses, the random-effects model was used.

Results: Seventeen articles met the inclusion criteria. The surgeries studied included total hip arthroplasty (seven), orthognathic surgery (eight), total knee arthroplasty (one) and spinal fusion (one). A total of 636 patients were randomized across all studies. For blood loss, the overall weighted mean difference favoured treatment, with a savings of about $287 \mathrm{~mL}$ of blood [95\% confidence interval (Cl): $-447,-127]$. The mean differences also showed a statistically significant benefit for deliberate hypotension in reducing transfusion requirements $(-667 \mathrm{~mL}$ of blood transfused; $95 \% \mathrm{Cl}:-963,-370)$. Deliberate hypotension was not shown to reduce the duration of surgery $(-1.9 \mathrm{~min}$ of surgery; $95 \% \mathrm{Cl}:-7.2,3.5)$ or improve surgical conditions (surgical field quality rating $-0.5 ; 95 \% \mathrm{Cl}$ : $-\mathrm{I} . \mathrm{I}, 0.2$ ).

Conclusion: This review provides some support for the use of deliberate hypotension in reducing blood loss and transfusion requirements in orthopedic surgery, but these results are tempered by the small sample sizes and poor methodological quality of published studies.
Objectif : Afin de déterminer si l'hypotension délibérée réduit les pertes sanguines et l'incidence transfusionnelle chez les patients subissant une chirurgie orthopédique, un compte-rendu systématique de toutes les études randomisées traitant de cette question $a$ été entrepris.

Méthode : Les bases de données électroniques, listes de citations et articles de compte-rendu ont été consultés afin de trouver des articles potentiellement pertinents. Les articles pertinents ont répondu aux critères suivants: langue anglaise, êtres humains subissant une chirurgie orthopédique, utilisation d'une méthode d'hypotension délibérée, quelle qu'elle soit, pertes sanguines peropératoires mesurées en tant que résultat, et méthodologie d'étude randomisée et contrôlée. Quatre évolutions ont été analysées, notamment les pertes sanguines estimées, le sang transfusé, la durée de la chirurgie et la qualité de l'hémostase chirurgicale. Un modèle à effets aléatoires a été utilisé pour toutes les analyses.

Résultats : Dix-sept articles ont répondu aux critères d'inclusion. Les chirurgies évaluées comprenaient : arthroplasties totales de la hanche (sept), chirurgies orthognathes (huit), arthroplastie totale du genou (une) et spondylodèse (une). Un total de 636 patients ont été randomisés dans ces études. En ce qui a trait à la perte sanguine, la différence moyenne pondérée totale a montré un résultat en faveur du traitement, avec une diminution des pertes sanguines d'environ $287 \mathrm{~mL}$ [95\% intervalle de confiance (IC) : -447, - 127]. Les différences moyennes ont également montré que l'hypotension délibérée présente des bienfaits statistiquement significatifs dans la réduction de l'incidence transfusionnelle (-667 $m L$ de sang transfusé; $95 \%$ IC: -963, -370). L'hypotension délibérée n'a pas eu d'influence sur la durée de chirurgie $(-1,9$ min de chirurgie ; $95 \%$ IC: $-7,2,3,5)$ ou sur l'amélioration des conditions chirurgicales (évaluation de la qualité de l'hémostase chirurgicale $-0,5 ; 95 \%$ IC : $-I, I, 0,2)$.

CAN J ANESTH $2007 / 54: 10 /$ pp 799-810

From the Department of Anesthesia, Hamilton Health Sciences, McMaster University, Hamilton, Ontario, Canada.

Address correspondence to: Dr. James E. Paul, Assistant Clinical Professor, McMaster University, Department of Anesthesia, Hamilton

Health Sciences, Hamilton General Site, 237 Barton Street East, Hamilton, Ontario L8L 2X2, Canada. Phone: 905-527-0271, ext 46698; Fax: 905-577-8023; E-mail: james_paul@sympatico.ca

Financial support: Hamilton Health Sciences, Department of Anesthesia Academic Fund.

Accepted for publication April 10, 2007.

Revision accepted July 6, 2007. 
Conclusion : Ce compte-rendu soutient dans une certaine mesure l'utilisation de l'hypotension délibérée pour réduire les pertes sanguines et l'incidence transfusionnelle lors de chirurgie orthopédique ; toutefois, ces résultats sont mitigés par les petites tailles d'échantillons et la pauvreté méthodologique des études publiées.

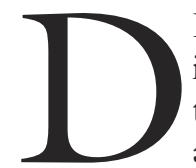
ELIBERATE hypotension was ushered into clinical practice prior to any controlled trials that established its safety and efficacy. ${ }^{1}$ The rationale for this blood conservation technique is to reduce the blood flow to the vessels within the surgical field so blood loss is reduced. At that time (1940s), transfusion practice was not well established and homologous transfusion was still considered somewhat controversial. ${ }^{2}$ Deliberate hypotension was initially considered to render otherwise inoperable patients operable. ${ }^{3} \mathrm{~A}$ cross-sectional survey of American and British anesthesiologists in 1954 showed that approximately $45 \%$ of respondents employed the technique. ${ }^{4}$ Initial enthusiasm for the technique waned following a report by Hampton and Little, describing a morbidity of $3.20 \%$ and a mortality of $0.34 \%$ based on 27,930 cases. ${ }^{5,6}$ Subsequent morbidity was reported at $2.5 \%$ and mortality between $0.02 \%$ and $0.60 \%$. The most common complications were delayed wakening, blurred vision and reactionary (delayed) hemorrhage. , $^{7-9}$ Given the potential risks of this intervention, it has been reserved for healthy patients. The technique is not generally used in patients with a history of cardiac, cerebrovascular, renal, hepatic, or severe peripheral vascular disease, uncorrected hypovolemia, or severe anemia. ${ }^{10}$

Persisting controversy exists regarding the value of deliberate hypotension. ${ }^{1}$ A number of trials have been published investigating this technique. Many studies have been uncontrolled or concentrated on the effects of the hypotensive agents, with only a few that have been randomized controlled studies. The results of the controlled studies are conflicting. Although there are a number of published review articles, ${ }^{1,5,7,8,10-34}$ all suffer from major methodological limitations. ${ }^{35}$ Lastly, none of the reviews attempted to obtain a quantitative estimate of the effect size of deliberate hypotension on blood loss and transfusion requirements.

Deliberate hypotension has been most extensively studied in major orthopedic procedures. ${ }^{1}$ In order to clarify if deliberate hypotension decreases blood loss and transfusion requirements in patients undergoing orthopedic surgery, we conducted a systematic review of all randomized trials reported in the English lan- guage. We specifically sought to determine whether or not deliberate hypotension decreases the amount of blood loss, reduces intraoperative transfusion requirements, improves the condition of the surgical field, and/or decreases the duration of surgery.

\section{Methods}

Study identification

Computerized searches of MEDLINE, the Cochrane Library, and EMBASE were conducted from the date of the first archived citation for each database until January 2006. MEDLINE search words were MeSH "controlled hypotension" or "controlled hypotension (tw) or "deliberate hypotension" (tw) or "hypotensive anesthesia" (tw) AND "randomized controlled trial" PTYP OR "drug therapy" SH OR "therapeutic use" OR "random" word. For the MEDLINE search, the sensitive search strategy for identifying randomized controlled trials of therapy, recommended by Haynes et al., was employed ${ }^{36}$ The Cochrane Library search string was: "controlled hypotension" OR "deliberate hypotension" OR "hypotensive anesthesia." The EMBASE search string: "controlled hypotension" OR "deliberate hypotension" OR "hypotensive anesthesia" AND "randomized controlled trial." The searches were designed to be sensitive and identify the maximum number of articles that addressed the topic of deliberate hypotension with a randomized controlled trial. The reference lists of selected primary research articles and review articles were examined for potentially relevant articles. Lastly, local experts in the area of orthopedics and anesthesia were contacted to provide any citations on additional studies.

After completing the literature search, the citation lists (titles, $\mathrm{MeSH}$, and abstracts where available) were independently reviewed by both authors (J.P. and E.L.). Full articles were obtained for all citations identified as potentially relevant by either reviewer.

\section{Study selection}

The reviewers were not blinded to the author names, affiliated institutions or the journal of publication of the studies. Any disagreements regarding inclusion of a study were resolved by consensus. Inclusion criteria were established a priori and were as follows:

1. Language: English language only

2. Population: Humans undergoing orthopedic surgery

3. Intervention: Deliberate hypotension by any method

4. Outcome: Outcomes included intraoperative blood loss 


\section{Methodology: Randomized controlled trials only}

\section{Study evaluation}

The authors (J.P., E.L., C.L.) completed an assessment of methodological quality of each study independently. ${ }^{37}$ The method of randomization and concealment of allocation were evaluated for each study. The level of blinding was evaluated for each study. A study was considered double-blind if it stated that neither the patient nor the study participants who evaluated outcomes could identify the treatment group to which patients were allocated. Completeness of follow-up was evaluated for each study. The percentage of follow-up was calculated from the ratio of the number of subjects who had outcomes recorded to the number of patients randomized into the study. A summary quality score was given to each study using a modified version of Jadad et al. ${ }^{37}$ In the original instrument, a study was given one point if there was explicit description of "withdrawals and dropouts." This requirement was changed if all of the patients who were registered into the study were accounted for in the results, then results for this study were given one point for appropriate description of withdrawals and dropouts.

\section{Data extraction}

The authors (J.P., E.L., and C.L.) completed data extraction independently for each study. Any disagreements regarding data extraction were resolved through consensus. Relevant information regarding population, intervention, and outcome were recorded on standardized study data sheets. This included contact information, study design, type of surgery, type of anesthetic, anesthetic drugs, patient position, number of subjects, subjects baseline characteristics, treatment groups, method of deliberate hypotension, mean arterial blood pressure during treatment, transfusion trigger, outcomes reported by the study, estimated blood loss, number of transfusions, volume of transfusions, scale used to assess the surgical field, the surgical field index score, the number of subjects accounted for in the results, and whether or not the authors of the study advocated deliberate hypotension.

\section{Analysis}

Consensus between reviewers was determined using a kappa statistic. Agreement was considered good with a kappa score greater than $0.60 .^{38}$ The primary outcome analyzed estimated intraoperative blood loss during the surgery. Secondary outcomes included volume of intraoperative blood transfused, surgical duration and surgical field quality. Analysis was conducted using the computer software program Stata 9.2 (Stat Corp., College Station, TX, USA). The analysis was based on the effect size for each individual study. When outcomes where measured in a standard way across studies, and there was no significant heterogeneity between effect sizes across studies, the pooled results were presented as weighted mean differences. Weighted mean differences were preferred so that the results could be presented in natural units. When outcomes were not reported in a standard way, or where there was significant heterogeneity in effect sizes across studies, the pooled results were presented as standardized mean differences. The standardized mean difference was derived by dividing the mean difference by a pooled estimate of the standard deviation of the effect measure for each study. Both the weighted mean difference and the standardized mean difference were calculated using a random effects model using the methods of DerSimonian and Laird. ${ }^{39}$ Specifically, individual effect sizes were weighted according to the reciprocal of their variance. For each outcome reported the effect size was reported with the associated $95 \%$ confidence interval (CI), in natural units for the weighted mean difference and in standard deviations for the standardized mean difference. The random effects model was employed in the analyses because it was assumed that the included studies were a random sample of a population of studies investigating deliberate hypotension. In cases where the standard deviation in effect size was not reported it was estimated by dividing the range by four. In cases where studies used multiple treatment groups only the first reported group treated with hypotension was included in the analysis to avoid multiple comparisons with a single control group. The test for heterogeneity was taken as the inverse variance estimate and was considered significant when $P<0.05$. The test statistic for pooled treatment effects was calculated as the ratio of the mean difference to its associated standard error, with significance set at $P<0.05$.

Subgroup analysis was limited to the outcome of a reduction in intraoperative blood loss, since this was the primary outcome addressed by the review. Subgroup analysis was conducted to explore potential sources of heterogeneity. Subgroups analyzed included the type of surgery, method of inducing hypotension, methodological quality (low: score $\leq 3$ ps high: score $>3$ ) and publication date (old: pre-1990 ps new: post- 1990).

\section{Results}

The computerized database searches and the search of review articles and primary studies yielded a total of 2,850 citations and reviewers identified 76 as 
TABLE I Study characteristics

\begin{tabular}{|c|c|c|c|c|c|c|c|c|}
\hline Reference & Surgery & Sample size & $\begin{array}{l}\text { Hypotension } \\
\text { technique }\end{array}$ & $\begin{array}{l}\text { Intraoperative } \\
\text { blood pressure } \\
(m m \mathrm{Hg})\end{array}$ & $\begin{array}{l}\text { Transfusion } \\
\text { trigger }\end{array}$ & $\begin{array}{l}\text { Methodology } \\
\text { score }\end{array}$ & $\begin{array}{l}\text { Blinding } \\
\text { (patient/ } \\
\text { surgeon/ } \\
\text { anesthesiologist) }\end{array}$ & $\begin{array}{l}\text { Lost to } \\
\text { follow-up }\end{array}$ \\
\hline $\begin{array}{l}\text { Barbier- } \\
\text { Bohm } \\
1980(40)\end{array}$ & $\begin{array}{l}\text { Total hip } \\
\text { arthroplasty }\end{array}$ & $\begin{array}{l}\text { Treatment } \\
\left(\mathrm{DH}^{*}\right): 11 \\
\text { Control } 1 \\
\left(\mathrm{HD}^{* *}\right): 9 \\
\text { Control } 2 \\
\text { (no DH, } \\
\text { no HD): } 10\end{array}$ & $\begin{array}{l}\text { Sodium } \\
\text { nitroprusside } \\
\text { None } \\
\text { None }\end{array}$ & $\begin{array}{l}55 \\
\text { Not reported } \\
\text { Not reported }\end{array}$ & $\begin{array}{l}\mathrm{EBL}>300 \mathrm{~mL} \\
\text { Discretion of } \\
\text { attending } \\
\text { physician }\end{array}$ & 1 & No / No / No & $\begin{array}{l}0 / 21 \\
(0 \%)\end{array}$ \\
\hline $\begin{array}{l}\text { Chan } \\
1980(41)\end{array}$ & $\begin{array}{l}\text { Orthognathic } \\
\text { surgery }\end{array}$ & $\begin{array}{l}\text { Treatment } \\
\text { (DH): } 11 \\
\text { Control } \\
\text { (no DH): } 10\end{array}$ & $\begin{array}{l}\text { Sodium } \\
\text { nitroprusside } \\
\text { None }\end{array}$ & $\begin{array}{l}66 \pm 11 \\
84 \pm 9\end{array}$ & Not reported & 1 & No / No / No & $\begin{array}{l}0 / 21 \\
(0 \%)\end{array}$ \\
\hline $\begin{array}{l}\text { Enlund } \\
1997 \text { (12) }\end{array}$ & $\begin{array}{l}\text { Orthognathic } \\
\text { surgery }\end{array}$ & $\begin{array}{l}\text { Treatment } \\
\text { (DH): } 20 \\
\text { Control } \\
\text { (no DH): } 20\end{array}$ & $\begin{array}{l}\text { Isoflurane } \\
\text { None }\end{array}$ & $\begin{array}{l}54-64 \\
68-95\end{array}$ & Not reported & 3 & No / Yes / No & $\begin{array}{l}4 / 40 \\
(10 \%)\end{array}$ \\
\hline $\begin{array}{l}\text { Felfernig- } \\
\text { Boehm } \\
2001(42)\end{array}$ & $\begin{array}{l}\text { Orthognathic } \\
\text { surgery }\end{array}$ & $\begin{array}{l}\text { Treatment } 1 \\
\text { (DH: } 10) \\
\text { Treatment } 2 \\
\text { (DH): } 10 \\
\text { Control: } \\
\text { (no DH): } 10\end{array}$ & $\begin{array}{l}\text { Nitroglycerin } \\
\text { Remifentanyl } \\
\text { None }\end{array}$ & $\begin{array}{l}59.3 \pm 3.6 \\
60.8 \pm 5.8\end{array}$ & $\begin{array}{l}\text { Not Reported } \\
\text { Not Reported }\end{array}$ & 2 & No / No / No & $\begin{array}{l}0 / 30 \\
(0 \%)\end{array}$ \\
\hline $\begin{array}{l}\text { Fromme } \\
1986(43)\end{array}$ & $\begin{array}{l}\text { Orthognathic } \\
\text { surgery }\end{array}$ & $\begin{array}{l}\text { Treatment } 1 \\
\text { (DH-low): } 17 \\
\text { Treatment } 2 \\
\text { (DH-very } \\
\text { low): } 21 \\
\text { Control } \\
\text { (no DH): } 18\end{array}$ & $\begin{array}{l}\text { Enflurane } \\
\text { Sodium } \\
\text { nitroprusside } \\
\text { None }\end{array}$ & $\begin{array}{l}75-85 \\
55-60 \\
90-100\end{array}$ & Not reported & 2 & No / Yes / No & $\begin{array}{l}0 / 56 \\
(0 \%)\end{array}$ \\
\hline $\begin{array}{l}\text { Fukusaki } \\
1997(44)\end{array}$ & $\begin{array}{l}\text { Total hip } \\
\text { arthroplasty }\end{array}$ & $\begin{array}{l}\text { Treatment } 1 \\
(\mathrm{DH}): 10 \\
\text { Treatment } 2 \\
(\mathrm{DH}+ \\
\mathrm{HD}): 10 \\
\text { Control } \\
(\mathrm{HD}, \text { no } \\
\mathrm{DH}): 10\end{array}$ & $\begin{array}{l}\text { Prostoglandin } \\
\text { El } \\
\text { Prostoglandin } \\
\text { El } \\
\text { None }\end{array}$ & $\begin{array}{l}56 \pm 2 \\
55 \pm 2 \\
90 \pm 3\end{array}$ & $\mathrm{EBL}>400 \mathrm{~mL}$ & 2 & $\mathrm{No} / \mathrm{No} / \mathrm{No}$ & $\begin{array}{l}0 / 30 \\
(0 \%)\end{array}$ \\
\hline $\begin{array}{l}\text { Grundy } \\
1982 \text { (45) }\end{array}$ & Spinal fusion & $\begin{array}{l}\text { Treatment } \\
\text { (DH): } 13 \\
\text { Control } \\
\text { (no DH): } 11\end{array}$ & $\begin{array}{l}\text { Sodium } \\
\text { nitroprusside } \\
\text { None }\end{array}$ & $\begin{array}{l}60 \pm 4.6 \\
72 \pm 13.6\end{array}$ & $\begin{array}{l}\text { Hct } \leq 25 \%- \\
\text { target }=35 \%\end{array}$ & 3 & No / Yes / No & $\begin{array}{l}0 / 24 \\
(0 \%)\end{array}$ \\
\hline $\begin{array}{l}\text { Juelsgaard } \\
2001(46)\end{array}$ & $\begin{array}{l}\text { Total knee } \\
\text { arthroplasty }\end{array}$ & $\begin{array}{l}\text { Treatment } \\
\text { (DH): } 14 \\
\text { Control } \\
\text { (no DH): } 16\end{array}$ & $\begin{array}{l}\text { Epidural } \\
\text { Ropivacaine } \\
\text { None }\end{array}$ & $\begin{array}{l}48 \pm 3 \\
83 \pm 12\end{array}$ & Hct $<28 \%$ & 2 & Yes / No / No & $\begin{array}{l}0 / 30 \\
(0 \%)\end{array}$ \\
\hline $\begin{array}{l}\text { Lessard } \\
1989(47)\end{array}$ & $\begin{array}{l}\text { Orthognathic } \\
\text { surgery }\end{array}$ & $\begin{array}{l}\text { Treatment } \\
(\mathrm{DH}): 25 \\
\text { Control } \\
\text { (no DH): } 27\end{array}$ & $\begin{array}{l}\text { Isoflurane } \\
\text { None }\end{array}$ & $\begin{array}{l}60.0 \pm 2.3 \\
80.7 \pm 4.4\end{array}$ & $\begin{array}{l}\mathrm{EBL}>20 \% \\
\text { of blood } \\
\text { volume }\end{array}$ & 5 & Yes / Yes / No & $\begin{array}{l}0 / 52 \\
(0 \%)\end{array}$ \\
\hline $\begin{array}{l}\text { Niemi } \\
2000(48)\end{array}$ & $\begin{array}{l}\text { Total hip } \\
\text { arthroplasty }\end{array}$ & $\begin{array}{l}\text { Treatment } \\
\text { (DH): } 15 \\
\text { Control } \\
\text { (no DH): } 15\end{array}$ & $\begin{array}{l}\text { Epidural } \\
\text { Bupivacaine } \\
\text { None }\end{array}$ & $\begin{array}{l}61 \pm 8 \\
84 \pm 13\end{array}$ & Hct $\leq 30 \%$ & 2 & No / No / No & $\begin{array}{l}0 / 30 \\
(0 \%)\end{array}$ \\
\hline
\end{tabular}

** $\mathrm{HD}=$ deliberate hypotension; ${ }^{*} \mathrm{DH}=$ hemodilution; $\mathrm{EBL}=$ estimated blood loss; Hct $=$ hematocrit. 
TABLE I Study characteristics - continued

\begin{tabular}{|c|c|c|c|c|c|c|c|c|}
\hline Reference & Surgery & Sample size & $\begin{array}{l}\text { Hypotension } \\
\text { technique }\end{array}$ & $\begin{array}{l}\text { Intraoperative } \\
\text { blood pressure } \\
(\mathrm{mmHg})\end{array}$ & $\begin{array}{l}\text { Transfusion } \\
\text { trigger }\end{array}$ & $\begin{array}{l}\text { Methodology } \\
\text { score }\end{array}$ & $\begin{array}{l}\text { Blinding } \\
\text { (patient/ } \\
\text { surgeon/ } \\
\text { anesthesiologist) }\end{array}$ & $\begin{array}{l}\text { Lost to } \\
\text { follow-up }\end{array}$ \\
\hline $\begin{array}{l}\text { Praveen } \\
2001(49)\end{array}$ & $\begin{array}{l}\text { Orthognathic } \\
\text { surgery }\end{array}$ & $\begin{array}{l}\text { Treatment } \\
(\mathrm{DH}): 24 \\
\text { Control } \\
\text { (no DH): } 29\end{array}$ & $\begin{array}{l}\text { Nitroglycerin } \\
\text { \& Esmolol } \\
\text { None }\end{array}$ & $\begin{array}{l}71.3 \\
94.6\end{array}$ & $\begin{array}{l}\text { Discretion of } \\
\text { attending } \\
\text { physician }\end{array}$ & 3 & No / No / No & $\begin{array}{l}0 / 53 \\
(0 \%)\end{array}$ \\
\hline $\begin{array}{l}\text { Precious } \\
1996(15)\end{array}$ & $\begin{array}{l}\text { Orthognathic } \\
\text { surgery }\end{array}$ & $\begin{array}{l}\text { Treatment } \\
(\mathrm{DH}): 25 \\
\text { Control } \\
\text { (no DH): } 25\end{array}$ & $\begin{array}{l}\text { Propranolol } \\
\text { None }\end{array}$ & $\begin{array}{l}\text { Within } 75 \% \\
\text { of baseline } \\
\text { Within } 10 \\
\text { mmHg of } \\
\text { baseline }\end{array}$ & Not reported & 2 & No / Yes / No & $\begin{array}{l}0 / 50 \\
(0 \%)\end{array}$ \\
\hline $\begin{array}{l}\text { Qvist } \\
1982(50)\end{array}$ & $\begin{array}{l}\text { Total hip } \\
\text { arthroplasty }\end{array}$ & $\begin{array}{l}\text { Treatment } \\
\text { (DH): } 16 \\
\text { Control } \\
\text { (no DH): } 16\end{array}$ & $\begin{array}{l}\text { Halothane } \\
\text { None }\end{array}$ & $\begin{array}{l}10.5 \pm 1.2 \\
14.1 \pm 2.0\end{array}$ & $\begin{array}{l}\text { Discretion of } \\
\text { attending } \\
\text { physician }\end{array}$ & 2 & No / No / No & $\begin{array}{l}0 / 32 \\
(0 \%)\end{array}$ \\
\hline $\begin{array}{l}\text { Rosberg } \\
1982(51)\end{array}$ & $\begin{array}{l}\text { Total hip } \\
\text { arthroplasty }\end{array}$ & $\begin{array}{l}\text { Treatment } \\
(\mathrm{DH}): 33 \\
\text { Control } \\
\text { (no DH): } 28\end{array}$ & $\begin{array}{l}\text { Sodium } \\
\text { nitroprusside } \\
\text { None }\end{array}$ & $\begin{array}{l}61 \pm 1.2(\mathrm{SE}) \\
85 \pm 2.1(\mathrm{SE})\end{array}$ & Not reported & 2 & No / No / No & $\begin{array}{l}0 / 61 \\
(0 \%)\end{array}$ \\
\hline $\begin{array}{l}\text { Thompson } \\
1978(52)\end{array}$ & $\begin{array}{l}\text { Total hip } \\
\text { arthroplasty }\end{array}$ & $\begin{array}{l}\text { Treatment } 1 \\
(\mathrm{DH}): 9 \\
\text { Treatment } 2 \\
(\mathrm{DH}): 9 \\
\text { Control } \\
(\text { no DH): } 12\end{array}$ & $\begin{array}{l}\text { Halothane } \\
\text { Sodium } \\
\text { nitroprusside } \\
\text { None }\end{array}$ & $\begin{array}{l}50 \\
50 \\
\text { Within 20\% } \\
\text { of baseline }\end{array}$ & Not reported & 2 & No / No / No & $\begin{array}{l}0 / 30 \\
(0 \%)\end{array}$ \\
\hline $\begin{array}{l}\text { Yukioka } \\
1993(53)\end{array}$ & $\begin{array}{l}\text { Total hip } \\
\text { arthroplasty }\end{array}$ & $\begin{array}{l}\text { Treatment } \\
(\mathrm{DH}): 29 \\
\text { Control } \\
\text { (no DH): } 28\end{array}$ & $\begin{array}{l}\text { Prostoglandin } \\
\text { El } \\
\text { None }\end{array}$ & $\begin{array}{l}71.0 \pm 8 \\
92.3 \pm 7\end{array}$ & $\mathrm{EBL}>300 \mathrm{~mL}$ & 2 & No / No / No & $\begin{array}{l}0 / 57 \\
(0 \%)\end{array}$ \\
\hline
\end{tabular}

${ }^{* *} \mathrm{HD}=$ deliberate hypotension; ${ }^{\mathrm{D}} \mathrm{DH}=$ hemodilution; $\mathrm{EBL}=$ estimated blood loss; Hct $=$ hematocrit.

potentially eligible. After detailed review of all eligible articles, 17 met the inclusion criteria. ${ }^{7,12,15,40-53}$ The weighted kappa on agreement between the reviewers in identifying eligible articles was 0.87 , which is consistent with near perfect agreement. Reasons for excluding the potentially relevant articles included the wrong population, the wrong intervention, no control group, estimated blood loss not recorded as an outcome, subjects not randomized to treatment groups, and the article being a review or editorial.

The 17 relevant studies are summarized in Table I. A total of 636 subjects were included in the studies, 341 received deliberate hypotension and 295 controls. The Jadad quality index score was 3 or less (out of 5 ) in 16 studies, reflecting the lack of blinding and absent description of a randomization method in the majority of the studies. Only one study had a perfect score of $5 .{ }^{47}$ In addition to the tabulated methodology features, it was found that none of the studies described whether or not there was adequate allocation concealment of patient randomization. The surgical population included patients undergoing orthognathic surgery (eight studies), total hip arthroplasty (seven studies), total knee arthroplasty (one study) and spinal fusion (one study). Six methods of deliberate hypotension were investigated: sodium nitroprusside, volatile anesthetic, prostaglandin $\mathrm{E}_{1}$, epidural blockade, remifentanil and propranolol. Usable data for analyzing the outcomes were available from 17 studies for estimated blood loss, seven studies for transfusion, 12 studies for surgical duration, and six studies for surgical field quality. The ordinal scales used to rate the surgical field for the six orthognathic studies with data are described in Table II. Four study scales rated the surgical field from 0 (best) to 5 (worst), one rated it from 1 (best) to 3 (worst) and one rated it from 10 (best) to 0 (worst). Two studies investigated the cointervention of hemodilution in addition to deliberate hypotension. ${ }^{40,44}$ In one study, the first control group received hemodilution (excluded from analysis) and a second control group did not. ${ }^{40}$ In the other study, two treatment groups received deliberate hypotension 
TABLE II Surgical field quality scales

\begin{tabular}{|c|c|}
\hline Reference & Scale \\
\hline Chan $^{41}$ & $\begin{array}{l}1=\text { Relatively dry field } \\
2=\text { In-between } \\
3=\text { Obscure }, \text { excessively bloody field }\end{array}$ \\
\hline Dolman ${ }^{7}$ & $\begin{array}{l}1 \text { = Minimal bleeding: not a surgical nuisance } \\
2 \text { = Mild bleeding: a nuisance but does not } \\
\text { compromise dissection } \\
3 \text { = Moderate bleeding: slightly compromises } \\
\text { dissection } \\
4 \text { = Severe bleeding: significantly compromises } \\
\text { dissection } \\
5 \text { = Massive bleeding: cannot carry out dissection }\end{array}$ \\
\hline Enlund $^{12}$ & $\begin{array}{l}\text { Visual analogue scale: } \\
0=\text { Least possible blood loss } \\
10=\text { Worst possible blood loss }\end{array}$ \\
\hline Fromme $^{43}$ & $\begin{array}{l}0=\text { No bleeding, virtually bloodless field } \\
1=\text { Bleeding, so mild it was not even a surgical } \\
\text { nuisance } \\
2=\text { Moderate bleeding, a nuisance but without } \\
\text { interference with accurate dissection } \\
3=\text { Moderate bleeding that moderately } \\
\text { compromised surgical dissection } \\
4=\text { Bleeding, heavy but controllable, that } \\
\text { significantly interfered with dissection } \\
5=\text { Massive uncontrollable bleeding }\end{array}$ \\
\hline Lessard ${ }^{47}$ & - Same as Fromme 43 \\
\hline Precious $^{15}$ & - Same as Fromme $e^{43}$ \\
\hline
\end{tabular}

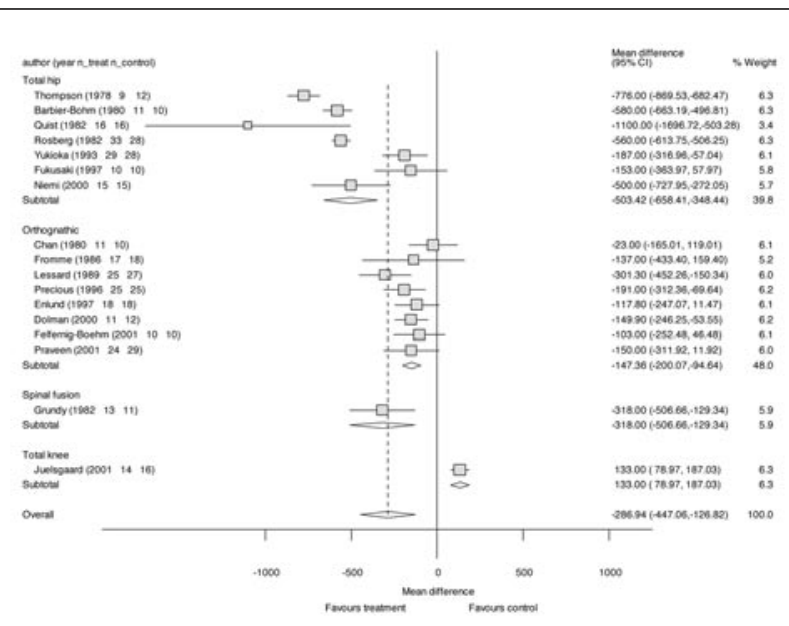

FIGURE 1 Weighted mean difference in estimated blood loss $(\mathrm{mL})$ between treatment and controls

Weighted mean differences were calculated with a random effects model and plotted with the $95 \%$ confidence intervals. Studies are listed by surgery type and then by year of publication.

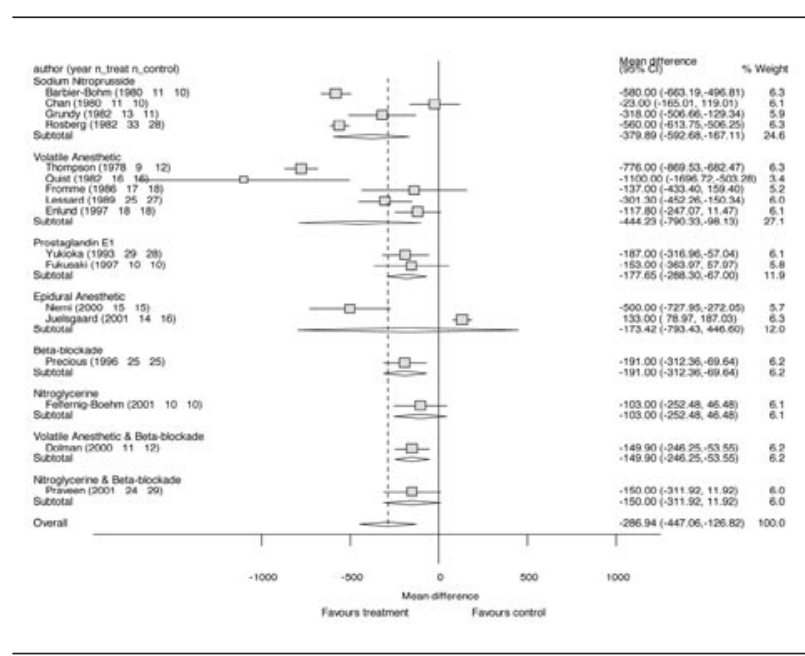

FIGURE 2 Weighted mean difference in (intraoperative) estimated blood loss $(\mathrm{mL})$ between treatment and controls grouped by hypotensive drug

Weighted mean differences were calculated with a random effects model and plotted with the $95 \%$ confidence intervals.

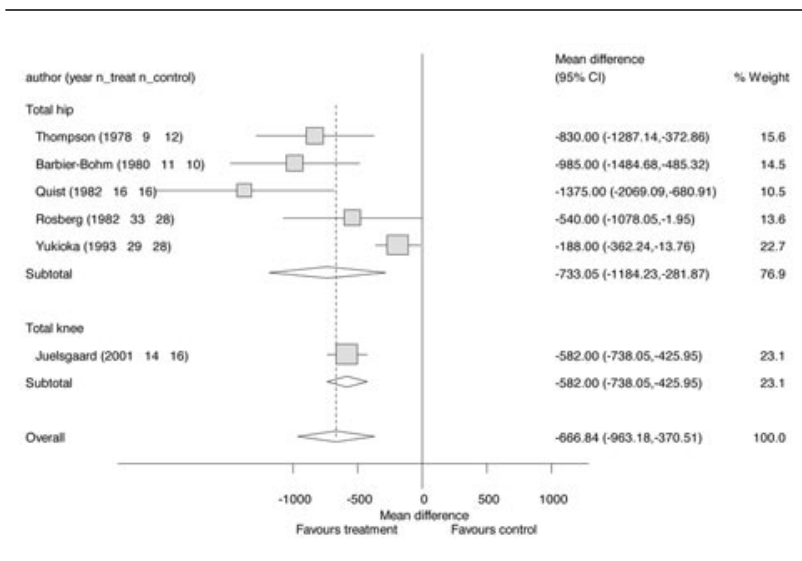

FIGURE 3 Weighted mean difference in volume of blood transfused

Weighted mean differences were calculated with a random effects model and plotted with the $95 \%$ confidence intervals. Studies are listed by surgery type and then by year of publication.

and one group also received hemodilution during surgery; the treatment group that received hemodilution was excluded from the analysis. ${ }^{44}$ The intraoperative mean blood pressure of the treatment and control groups was described by 16 of the studies; the remaining study reported the maintaining of blood pressure within $75 \%$ of baseline value for the treatment group. ${ }^{15}$ 


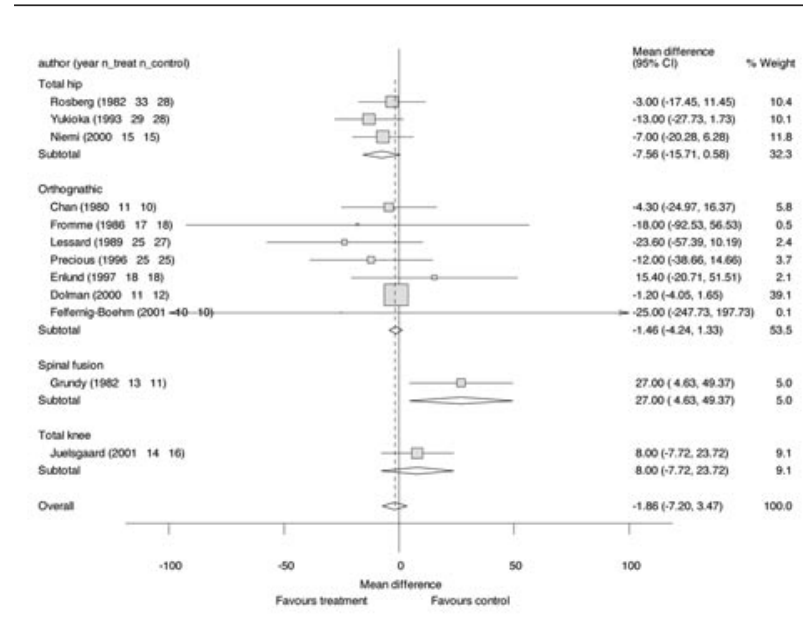

FIGURE 4 Weighted mean difference in surgical duration (min) for the individual studies

Weighted mean differences were calculated with a random effects model and plotted with the $95 \%$ confidence intervals. Studies are listed by surgery type and then by year of publication.

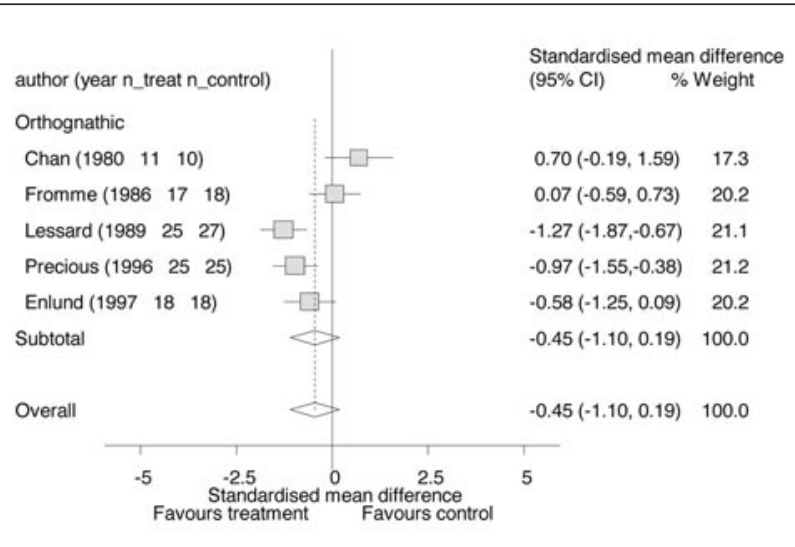

FIGURE 5 Standardized mean difference (SD) in surgical field quality for the individual studies

Standardized mean differences were calculated with a random effects model and plotted with the $95 \%$ confidence intervals. Studies are listed by surgery type and then by year of publication.

In the studies which described the intraoperative blood pressure of the treatment group, the measured mean blood arterial ranged from 48 to $78 \mathrm{mmHg}$. The transfusion trigger was not reported in eight of the studies, $7,12,15,41-43,51,52$ it was left to the discretion of the attending anesthesiologist in two studies ${ }^{49,50}$ and it was explicitly stated in the remaining seven studies. ${ }^{40,44-48,53}$

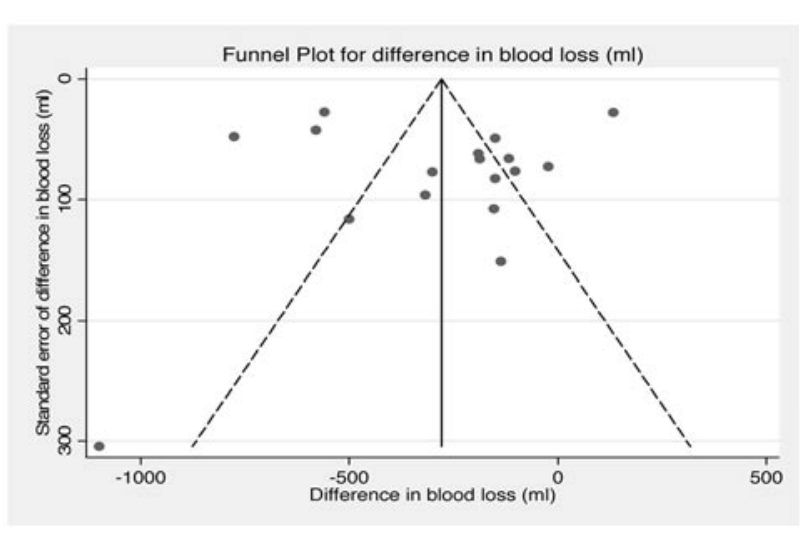

FIGURE 6 Funnel plot: difference in blood loss between the treatment (hypotension) groups vs controls. The funnel plot is centered on the pooled estimate for difference in blood loss. Egger's test for bias was non-significant, $P=$ 0.955 .

In the studies which described the transfusion triggers, the triggers included volume of blood loss (300-400 $\mathrm{mL}$ ), hematocrit thresholds (28-30\%), and percentage of blood volume lost (20\%).

Analysis for blood loss, transfusion, surgical duration, and surgical field quality are shown in Figures 1 to 5 respectively. Point estimates less than 0 (to the left) favour deliberate hypotension; estimates greater than 0 (to the right) favour controls. The overall (pooled) estimates are displayed as diamonds at the bottom of the figures. For blood loss, the overall weighted mean difference favoured treatment, with a savings of about $286 \mathrm{~mL}$ of blood $(95 \% \mathrm{CI}:-447,-127)$. The mean differences also showed a statistically significant benefit for deliberate hypotension in reducing transfusion requirements $(-667 \mathrm{~mL}$ of blood transfused; 95\% CI: $-963,-370)$. Deliberate hypotension was not found to reduce surgery duration (-1.9 min of surgery; $95 \%$ CI: -7.2, 3.5) or improve surgical conditions (surgical field quality rating $-0.5 ; 95 \% \mathrm{CI}:-1.1,0.2)$. Fourteen of the 17 studies advocated the use of deliberate hypotension in the discussion. ${ }^{7,15,40-42,45-52}$

Three studies reported the numbers of patients that did and did not receive any blood transfusion. ${ }^{40,43,46}$ Overall, the incidence of receiving a blood transfusion in the hypotensive groups was $55.8 \%$ vs $78.7 \%$ in the control groups. This resulted in a number needed-totreat (with deliberate hypotension) of 4.4 .

The results of the subgroup analyses are presented in Figures 1 through 5; results are grouped by surgery type in Figures 1, 3-5, and by hypotensive drug in Figure 2. For reduction in blood loss, the statistically 
TABLE III Patient harm

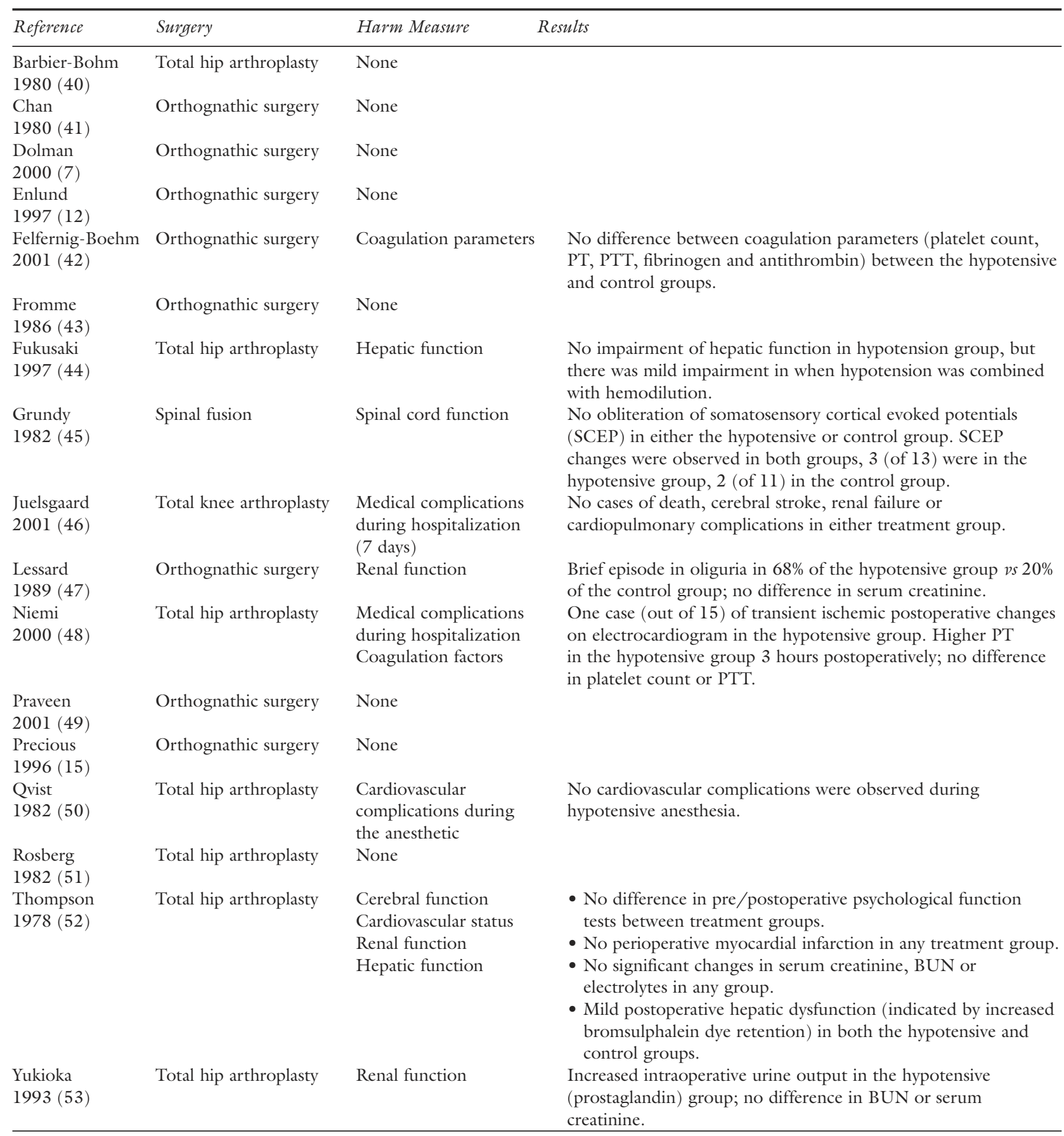

PT $=$ prothrombin time $;$ PTT $=$ partial thromboplastin time $; \mathrm{BUN}=$ blood urea nitrogen.

significant effect is consistent for all surgical procedures except total knee arthroplasty and across the different methods used to produce deliberate hypotension. For blood loss reduction, there was significant heterogeneity $(P<0.001)$ between subgroups of all surgery types except orthognathic surgery and for all hypotensive drugs except prostoglandin $\mathrm{E}_{1}(P<0.0001)$. Further, the reduction in blood loss was similar for low (score $\leq 3$ ) vs high (score $>3$ ) quality studies and for older (pre- 1990) vs newer (post- 1990) studies. 
Table III summarizes patient harm parameters that were recorded by the studies. Eight studies did not record any information on patient harm. One study found a higher incidence of intraoperative oliguria in orthognathic surgery patients treated with isoflurane-induced hypotension; ${ }^{47}$ by contrast, intraoperative urine output was increased in another study of hip arthroplasty patients treated with prostoglandin-induced hypotension. ${ }^{53}$ Otherwise, none of the remaining studies found a difference in death rate ${ }^{45,48}$ or cerebral, ${ }^{52}$ cardiopulmonary, ${ }^{46,48,50}$ renal $^{47,52,53}$ or hepatic ${ }^{4,52}$ complications.

Figure 6 shows a funnel plot for the difference in blood loss between the treatment (hypotension) groups $v s$ controls. The plot is fairly symmetrical around the pooled estimate for blood loss difference and the Egger's test for bias was non-significant $(P=$ $0.955)$, suggesting that there was no publication bias with missing small negative trials.

\section{Discussion}

This review addressed specific clinical questions: does deliberate hypotension during orthopedic surgery reduce intraoperative blood loss, intraoperative transfusion requirements, and surgical duration and improve the quality of the surgical field? The results of the meta-analysis show that the use of deliberate hypotension for orthognathic surgery, total hip arthroplasty, and spinal fusion resulted in a significant reduction in blood loss. Although deliberate hypotension did not reduce intraoperative blood loss for the one trial of total knee arthroplasty, it did reduce the blood loss postoperatively (one hour, two hours, three hours and $24 \mathrm{hr}$ ). ${ }^{46}$ Further, the intraoperative comparison was biased towards the control group in this study because that group was treated with an intraoperative tourniquet whereas the treatment group was not. The effect of deliberate hypotension (reduction in intraoperative blood loss) was consistent for all the different methods used to produce deliberate hypotension. Although significant heterogeneity was found between the subgroups of surgery types and drugs used to produce hypotension, this should be accounted for in the random effects model used for the analysis. Also, the reduction in intraoperative blood loss was similar for low and high quality studies, as well as for older and newer studies. Deliberate hypotension also reduced transfusion requirements for total hip and total knee arthroplasty, but it should be noted that ten of the 17 studies did not have a transfusion protocol and the decision was left to the discretion of the attending anesthesiologist. Further, several of the transfusion protocols were very conser- vative (e.g., transfusion when estimated blood loss was $>300 \mathrm{~mL}$ ) and not applicable to young healthy patients. Deliberate hypotension was not found to reduce the duration of surgery or improve the quality of the surgical field for orthopedic surgery. These results are based on a sample of patients that were generally healthy and did not have any clinical evidence of cardiac or respiratory disease.

The results of this review should be valid based on the recommendations suggested for meta-analyses. ${ }^{54,55}$ Strengths of the review include the identification of a focused question, clear description of study search and selection criteria, reproducible selection criteria, reproducible assessment of the validity of included studies, description of the methods and criteria for pooling of studies, and similar results from study to study that were robust to both subgroup and sensitivity analysis. The review is limited by the fact that it includes only published studies, was restricted to English language publications, and pooled the results of studies that may be quite heterogeneous. Despite the lack of unpublished studies in this review there was no indication of publication bias from the funnel plot (which was symmetrical) or the Egger's test (which was non-significant). ${ }^{56}$

The tests for heterogeneity in the overall pooled analysis for all four outcomes (blood loss, transfusion, surgical duration, and surgical field quality) were significant. Subgroup analysis that grouped studies by surgery and then by method of deliberate hypotension reduced some of this heterogeneity, suggesting that the difference in effect sizes is partially explained by the differences in surgical procedures and methods of producing hypotension. Despite the statistically significant heterogeneity, the individual study results for reduction in blood loss were qualitatively the same. The heterogeneity in the treatment effect sizes was partially accounted for in the method of analysis used in this review. The random effects model incorporates study variation in calculating the pooled estimate of effect size and the resulting CIs generated are wider than if a fixed effects model had been used.

This review provides important information regarding the clinical benefits of deliberate hypotension. Caution is warranted when interpreting the results of subgroup analyses, but it appears that deliberate hypotension reduces blood loss most effectively for total hip arthroplasty $(503 \mathrm{~mL}$ reduction), followed by spine fusion $(318 \mathrm{~mL}$ reduction), with the smallest benefit seen in orthognathic surgery $(147 \mathrm{~mL}$ reduction). All of the orthopedic procedures included in this review have the potential for significant blood loss, and possible requirement for blood transfusion. 
The clinical significance depends on patient co-morbidity and the specific surgical procedure considered. For total hip arthroplasty, a $500 \mathrm{~mL}$ reduction in blood loss would benefit many patients, whereas for orthognathic surgery a $150 \mathrm{~mL}$ reduction would have a trivial clinical impact. For orthognathic surgery, the main indication for deliberate hypotension is often improvement in surgical field quality (not reduction of blood loss) because the patient population is usually young and healthy.

The studies cited span a period of just over two decades (1978-2001). The fact that trials continue to examine deliberate hypotension illustrates the ongoing controversy regarding the clinical utility of this technique. Practice guidelines for perioperative blood transfusion and adjuvant therapies were recently published and deliberate hypotension is listed as one of the blood conservation techniques to be considered. ${ }^{57}$

None of the randomized trials in this review was designed for, or powered sufficiently to assess patient harm. All were relatively small trials that were not sufficiently large to detect possible differences in harm between the treatment and control groups. Of the nine studies that reported information on patient harm, there were no reported deaths and no differences in the reported frequencies of cardiopulmonary, renal or hepatic complications between the hypotensive and control groups. The mortality associated with deliberate hypotension was reported to be $0.29 \%$ (amongst 27,930 cases) in the 1950 s, $0.62 \%$ (amongst 13,264 cases) in the early 1960s, and more recent estimates have not been published. ${ }^{4,58}$ In reality, the risk of death with deliberate hypotension is likely no greater than the risk with general anesthesia which has been estimated to be between 0.014 to $0.03 \%{ }^{59,60}$ Further study is required to clarify the potential harm of deliberate hypotension and this will require studies specifically designed to detect harm (death and organ dysfunction), with sufficiently large sample sizes. For evaluation of rare adverse outcomes including death, a clinical trial is not generally feasible and such assessments may be best addressed with a large prospective cohort study.

If the primary concern were to eliminate transfusion risk associated with the transmission of viral infections such as hepatitis and HIV, it would be desirable to reduce the number of patients requiring even a single unit of blood. From that perspective, deliberate hypotension was shown to reduce the risk of transfusion and the number needed-to-treat was 4.4. This estimate is limited by the fact that it is based on only three of the 17 studies (with applicable data) and there was marked variability in the transfusion triggers used by the studies.
In conclusion, this review provides some support for the use of deliberate hypotension in reducing blood loss and transfusion requirements during orthopedic surgery, but not for improving surgical field quality or reducing surgical duration. Studies to date have generally been small and of variable, and sometimes of poor methodological quality. Evidence to date suggests that a simple, large, well-designed study is still warranted to clearly establish the role of deliberate hypotension in the perioperative setting.

\section{References}

1 Sollevi A. Hypotensive anesthesia and blood loss. Acta Anaesthesiol Scand Suppl 1988; 89: 39-43.

2 Lawson NW, Thompson DS, Nelson CL, Flacke JW, North ER. Sodium nitroprusside-induced hypotension for supine total hip replacement. Anesth Analg 1976; 55: 654-62.

3 Safar P. A study of deliberate hypotension in anesthesia, with special consideration of surgical blood loss in comparable groups of normotensive and hypotensive anesthesia. Surgery 1955; 37: 1002-18.

4 Little DM. Induced hypotension during anesthesia and surgery. Anesthesiology 1955; 16: 320-32.

5 Eckenhoff JE. Deliberate hypotension. Anesthesiology 1978; 48: 87-8.

6 Hampton LJ, Little DM. Complications associated with the use of controlled hypotension in anesthesia. AMA Arch Surg 1953; 67: 549-56.

7 Dolman RM, Bentley KC, Head TW, English M. The effect of hypotensive anesthesia on blood loss and operative time during Le Forte I osteotomies. J Oral Maxillofac Surg 2000; 58: 834-9.

8 Larson $A G$. Deliberate hypotension. Anesthesiology 1964; 25: 682-706.

9 Ditzler JW, Eckenhoff JE. A comparison of blood loss and operative time in certain surgical procedures completed with and without controlled hypotension. Ann Surg 1956; 143: 289-93.

10 Van Aken H, Miller ED Jr. Deliberate hypotension. In: Miller RD (Ed.). Anesthesia, $5^{\text {th }}$ ed. NY: Churchill Livingston; 2000: 1470-90.

11 Robling R, Zimmermann AP, Biro P, Haers PE, Sailer $H F$. Alternative methods for reduction of blood loss during elective orthognathic surgery. Int J Adult Orthodon Orthognath Surg 1999; 14: 77-82.

12 Enlund MG, Ablstedt BL, Andersson LG, Krekmanov $L I$. Induced hypotension may influence blood loss in orthognathic surgery, but it is not crucial. Scand J Plast Reconstr Surg Hand Surg 1997; 31: 311-7.

13 Shapira Y, Gurman G, Artru AA, et al. Combined hemodilution and hypotension monitored with jugular bulb oxygen saturation, EEC, and ECG decreases 
transfusion volume and length of ICU stay for major orthopedic surgery. J Clin Anesth 1997; 9: 643-9.

14 Hartmann T, Winkler M, Preis C, Germann P, Donner $A$, Muller $C$. Critical evaluation of blood-saving measures for high-risk patients. Acta Anaesthesiol Scand Suppl 1997; 111: 207-9.

15 Precious DS, Splinter W, Bosco D. Induced hypotensive anesthesia for adolescent orthognathic surgery patients. J Oral Maxillofac Surg 1996; 54: 680-3.

16 Hack H, Mitchell V. Hypotensive anaesthesia. Br J Hosp Med 1996; 55: 482-5.

17 Gombotz H, Stubenvoll E. Avoiding homologous blood and blood products in the perisurgical setting. Acta Anaesthesiol Scand Suppl 1996; 109: 138-9.

18 Schindler I, Andel H, Leber J, Kimla T. Moderate induced hypotension provides satisfactory operating conditions in maxillofacial surgery. Acta Anaesthesiol Scand 1994; 38: 384-7.

19 Sharrock NE, Mineo R, Urquhart B, Salvati EA. The effect of two levels of hypotension on intraoperative blood loss during total hip arthroplasty performed under lumbar epidural anesthesia. Anesth Analg 1993; 76: 580-4.

20 Tate DE, Friedman RJ. Blood conservation in spinal surgery. Review of current techniques. Spine 1992; 17: 1450-6.

21 Blau WS, Kafer ER, Anderson JA. Esmolol is more effective than sodium nitroprusside in reducing blood loss during orthognathic surgery. Anesth Analg 1992; 75: 172-8.

22 An HS, Mikhail WE, Jackson WT, Tolin B, Dodd $G A$. Effects of hypotensive anesthesia, nonsteroidal antiinflammatory drugs, and polymethylmethacrylate on bleeding in total hip arthroplasty patients. J Arthroplasty 1991; 6: 245-50.

23 Goldberg ME, McNulty SE, Azad SS, et al. A comparison of labetalol and nitroprusside for inducing hypotension during major surgery. Anesth Analg 1990; 70: 537-42.

24 Fahmy NR, Bottros MR, Charchaflich J, Matta EB, Sunder N. A randomized comparison of labetalol and nitroprusside for induced hypotension. J Clin Anesth 1989; 1: 409-13.

25 Porter SS, Asher M, Fox DK. Comparison of intravenous nitriprusside, nitroprusside-captopril, and nitroglycerin for deliberate hypotension during posterior spine fusion in adults. J Clin Anesth 1988; 1: 87-95.

26 Simpson DL, MacRae WR, Wildsmith JA, Dale BA. Acute beta-adrenoreceptor blockade and induced hypotension. Anaesthesia 1987; 42: 243-8.

27 Gallagher DM, Milliken RA. Induced hypotension for orthognathic surgery. J Oral Surg 1979; 37: 47-51.

28 Mostarlic O, Reiger V, Lazarevic Z. Controlled hypo- tension induced by sodium nitroprusside. A practical approach. Acta Anaesthesiol Belg 1976; 27 Suppl: 55-66.

29 Phillips W, Hensinger RN. Control of blood loss during scoliosis surgery. Clin Orthop Relat Res 1988; 229: 88-93.

30 Bunker JP. Anesthetic effects on surgical blood loss. Ann NY Acad Sci 1964; 115: 418-21.

31 Anderson JA. Deliberate hypotensive anesthesia for orthognatic surgery: controlled pharmacological manipulation of cardiovascular physiology. Int J Adult Orthodon Orthognath Surg 1986; 1: 133-59.

32 Sharrock NE, Salvati EA. Hypotensive epidural anesthesia for total hip arthroplasty: a review. Acta Orthop Scand 1996; 67: 91-107.

33 Fabmy NM. Indications and contraindications for deliberate hypotension with a review of of its cardiovascular effects. Int Anesthesiol Clin 1979; 17: 175-87.

34 Kashimoto S, Nakamura T, Yamaguchi T. Prostoglandin El reduces blood loss during and after resection of lumbar herniated disc. J Anesth 1992; 6: 294-6.

35 Oxman AD, Guyatt GH. Guidelines for reading literature reviews. CMAJ 1988; 138: 697-703.

36 Haynes RB, Wilczynski N, McKibbon KA, Walker CJ, Sinclair JC. Developing optimal search strategies for detecting clinically sound studies in MEDLINE. J Am Med Infrom Assoc 1994; 1: 447-58.

37 Jadad AM, Moore RA, Carroll D, et al. Assessing the quality of reports of randomized clinical trials: is blinding necessary? Control Clin Trials 1996; 17: 1-12.

38 Sackett DL, Haynes RB, Tugwell P, Guyatt G. Clinical Epidemiology: A Basic Science for Clinical Medicine, 2nd ed. Lippincott Williams \& Wilkins; 1991.

39 DerSimonian $R$, Laird N. Meta-analysis in clinical trials. Control Clin Trials 1986; 7: 177-88.

40 Barbier-Bohm G, Desmonts JM, Couderc E, Moulin D, Prokocimer P, Oliver H. Comparative effects of induced hypotension and normovolaemic haemodilution on blood loss in total hip arthroplasty. Br J Anaesth 1980; 52: 1039-43.

41 Chan W, Smith DE, Warer WH. Effects of hypotensive anesthesia in anterior maxillary osteotomy. J Oral Surg 1980; 38: 504-8.

42 Felfernig-Boehm D, Salat A, Kinstner C, et al. Influence of hypotensive and normotensive anesthesia on platelet aggregability and hemostatic markers in orthognathic surgery. Thromb Res 2001; 103: 185-92.

43 Fromme GA, MacKenzie RA, Gould AB, Lund BA, offord KP. Controlled hypotension of orthognathic surgery. Anesth Analg 1986; 65: 683-6.

44 Fukusaki M, Maekawa T, Yamaguchi K, Matsumoto $M$, Shibata O, Sumikawa K. Combined effects of 
prolonged prostaglandin El-induced hypotension and haemodilution on human hepatic function. Eur J Anaesthesiol 1997; 14: 157-63.

45 Grundy BL, Nash CL, Brown RH. Deliberate hypotension for spinal fusion: prospective randomized study with evoked potential monitoring. Can Anaesth Soc J 1982; 29: 452-62.

46 Juelsgaard P, Larsen UT, Sorensen JV, Madsen F, Soballe K. Hypotensive epidural anethesia in total knee replacement without tourniquet: reduced blood loss and transfusion. Reg Anesth Pain Med 2001; 26: 105-10.

47 Lessard MR, Trepanier CA, Baribault JP. Isofluraneinduced hypotension in orthognathic surgery. Anesth Analg 1989; 69: 379-83.

48 Niemi TT, Pitkanen M, Syrjala M, Rosenberg PH. Comparison of hypotensive epidural anaesthesia and spinal anaesthesia on blood loss and coagulation during and after total hip arthroplasty. Acta Anaesthesiol Scand 2000; 44: 457-64.

49 Praveen K, Narayanan V, Muthusekhar MR, Baig MF. Hypotensive anaesthesia and blood loss in orthognathic surgery: a clinical study. Br J Oral Maxillofac Surg 2001; 39: 138-40.

50 Qvist TF, Skovsted P, Bredgaard Sorensen M. Moderate hypotensive anaesthesia for reduction of blood loss during total hip replacement. Acta Anaesthesiol Scand 1982; 26: 351-3.

51 Rosberg B, Fredin H, Gustafson C. Anesthetic techniques and surgical blood loss in total hip arthroplasty. Acta Anaesthesiol Scand 1982; 26: 189-93.

52 Thompson GE, Miller RD, Stevens WC, Murray WR. Hypotensive anesthesia for total hip arthroplasty: a study of blood loss and organ function (brain, heart, liver and kidney). Anesthesiology 1978; 48: 91-6.

53 Yukioka $H$, Asada K, Fujimori M, Shimazu A.

Prostoglandin El as a hypotensive drug during general anesthesia for total hip replacement. J Clin Anesth 1993; 5: 310-4.

54 Oxman AD, Cook DJ, Guyatt GH. User's guides to the medical literature. VI. How to use an overview. Evidenced-Based Medical Working Group. JAMA 1994; 272: 1367-71.

55 Pogue J, Yusuf S. Overcoming the limitations of current meta-analysis of randomised controlled trials. Lancet 1998; 351: 47-52.

56 Thornton A, Lee P. Publication bias in meta-analysis: its causes and consequences. J Clin Epidemiol 2000; 53: 207-16.

57 American Society of Anesthesiologists Task Force on Perioperative Blood Transfusion and Adjuvant Therapies. Practice guidelines for perioperative blood transfusion and adjuvant therapies: an updated report by the American Society of Anesthesiologists Task Force on Perioperative Blood Transfusion and Adjuvant Therapies. Anesthesiology 2006; 105: 198208.

58 Enderby GE. A report on mortality and morbidity following 9,107 hypotensive anaesthetics. Br J Anaesth 1961; 33: 109-13.

59 Arbous MS, Grobbee DE, van KleefJW, et al. Mortality associated with anaesthesia: a qualitative analysis to identify risk factors. Anaesthesia 2001; 56: 1141-53.

60 Kawashima $\Upsilon$, Takahashi S, Suzuki M, et al. Anesthesiarelated mortality and morbidity over a 5 -year period in 2,363,038 patients in Japan. Acta Anaesthesiol Scand 2003; 47: 809-17. 